\title{
Noninfectious Pulmonary Complications
}

\author{
Enric Carreras and Kenneth R. Cooke
}

\subsection{Introduction}

Lung injury occurs frequently following HSCT and significantly contributes to morbidity and mortality in the immediate post transplant period and in the months and years that follow. It can be observed in 25-55\% of recipients (Cooke and Yanik 2016).

Historically, approximately half of all pulmonary complications seen after HSCT were secondary to infection, but the judicious use of broad-spectrum antimicrobial agents has tipped the balance toward noninfectious causes.

Noninfectious lung injury following HSCT may be mediated by either immune or nonimmune mechanisms and could represent up to the $50 \%$ of noninfectious mortality after allo-HSCT.

These complications have been classified by the American Thoracic Society according to the

E. Carreras $(\bowtie)$

Spanish Bone Marrow Donor Registry,

Josep Carreras Foundation and Leukemia Research

Institute, Barcelona, Catalunya, Spain

Hospital Clinic Barcelona, Barcelona University,

Barcelona, Catalunya, Spain

e-mail: enric.carreras@fcarreras.es

K. R. Cooke

Pediatric Blood and Marrow Transplantation

Program, Oncology Department, Sidney Kimmel

Comprehensive Cancer Center, Johns Hopkins

University School of Medicine, Baltimore, MD, USA tissue primarily injured and its etiology (Panoskaltsis-Mortari et al. 2011) (Table 52.1).

Table 52.1 Noninfectious pulmonary complications after HSCT ${ }^{\mathrm{a}}$

\begin{tabular}{|c|c|}
\hline Localization & Entity \\
\hline $\begin{array}{l}\text { Pulmonary } \\
\text { parenchyma }\end{array}$ & $\begin{array}{l}\text { - Acute interstitial pneumonitis }{ }^{\mathrm{b}} \\
\text { - Acute respiratory distress } \\
\text { syndrome (ARDS) } \\
\text { - BCNU pneumonitis } \\
\text { - Radiation pneumonitis } \\
\text { - Delayed pulmonary toxicity } \\
\text { syndrome } \\
\text { - Post-HSCT lymphoproliferative } \\
\text { disease (see Chap. 45) } \\
\text { - Eosinophilic pneumonia } \\
\text { - Pulmonary alveolar proteinosis }\end{array}$ \\
\hline $\begin{array}{l}\text { Vascular } \\
\text { endothelium }\end{array}$ & $\begin{array}{l}\text { - Peri-engraftment respiratory } \\
\text { distress syndrome (PERDS) } \\
\text { - Capillary leak syndrome }(\mathrm{CLS})^{\mathrm{b}} \\
\text { (see Chap. 42) } \\
\text { - Diffuse alveolar hemorrhage } \\
\text { (DAH) }^{\mathrm{b}} \\
\text { - Pulmonary VOD } \\
\text { - Transfusion-assoc. acute lung } \\
\text { injury } \\
\text { - Pulmonary cytolytic syndrome } \\
\text { - Pulmonary arterial hypertension } \\
\text { - Pulmonary thromboembolism }\end{array}$ \\
\hline $\begin{array}{l}\text { Airway } \\
\text { epithelium }\end{array}$ & $\begin{array}{l}\text { - Cryptogenetic organizing } \\
\text { pneumonia }(\mathrm{COP})^{\mathrm{b}, \mathrm{c}} \\
\text { - Bronchiolitis obliterans syndrome } \\
{ }^{(\mathrm{BOS})^{\mathrm{b}}}\end{array}$ \\
\hline
\end{tabular}

amportantly, this classification does not include the most frequent lung complication after HSCT, i.e., pulmonary edema secondary to fluid overload ${ }^{\mathrm{b}}$ All these complications are categorized as IPS ${ }^{\mathrm{c}}$ Formerly called bronchiolitis obliterans organizing pneumonia (BOOP) 


\subsection{Diagnostic Methodology of Pulmonary Complications}

Ideally, any respiratory/pulmonary complication observed after HSCT must be evaluated following a predetermined institutional protocol (Lucena et al. 2014), which should include:

1. Noninvasive tests: Blood samples for culture and antigen determination, sputum culture, nasopharyngeal swabs testing CMV, respiratory syncytial virus (RSV), Legionella, Pneumocystis jirovecii (PJ), parainfluenza virus (PIV), adenovirus (ADV), as well as urinary antigen tests and chest $\mathrm{x}$-ray.

2. If negative $\rightarrow$ empirical treatment (variable behavior; some centers start empirical treatment before the BAL, but many others start the treatment after BAL).

3. If no response in a maximum of $2-3$ days (or if galactomannan $(\mathrm{GM})+) \rightarrow$

(a) High-resolution chest-computed tomography (HRCT).

(b) Fiber-optic bronchoscopy (FOB) including bronchial aspiration and BAL to analyze: PCR for Legionella, Mycoplasma, Chlamydia, herpesvirus (all), polyomavirus, ADV, parvovirus, enterovirus, and respiratory virus (RSV; influenza a, B, and $\mathrm{C}$; PIV types 1-4; rhinovirus; bocavirus; metapneumovirus; and others) and GM.

4. In some selected cases, a transbronchial biopsy could be considered.

\subsubsection{Results Reported Using this Methodology (Seo et al. 2015; Lucena et al. 2014; Shannon et al. 2010)}

Diagnostic yield could be as high as $80 \%$.

Sixty percent of diagnosis is achieved with noninvasive techniques.

FOB/BAL permits an etiological diagnosis in up to $78 \%$ of cases.

In suspected IPS, a BAL study may detect a pathogen in $\sim 50 \%$ of cases.
For pathogen detection, early FOB ( $<5$ days) offer better yield than late FOB.

The risk of complications with FOB is $<5 \%$.

\subsection{Pulmonary Edema Due to Fluid Overload}

Despite not being included in most classifications of pulmonary complications after HSCT, pulmonary edema (PE) as a consequence of a fluid overload (FO) is extremely frequent (Rondón et al. 2017).

\begin{tabular}{|c|c|}
\hline Incidence & $\begin{array}{l}\text { FO may be observed in up to } 60 \% \text { of } \\
\text { patients in the first days after } \\
\text { HSCT. The exact incidence of PE is not } \\
\text { established although it could be higher } \\
\text { than } 20 \%\end{array}$ \\
\hline $\begin{array}{l}\text { Symptoms } \\
\text { and signs }\end{array}$ & $\begin{array}{l}\text { - Weight gain, moderate breathlessness, } \\
\text { nonproductive cough, moderate } \\
\text { hypoxemia } \\
\text { - Crackles and rales in both lung bases } \\
\text { - Chest radiology with diffuse alveolar/ } \\
\text { interstitial infiltrates }\end{array}$ \\
\hline Diagnosis & $\begin{array}{l}\text { PE should be suspected in the context of } \\
\text { weight gain, an increased cardiothoracic } \\
\text { index, and crackles/rales. Though rarely } \\
\text { necessary, the diagnosis can be } \\
\text { confirmed by pulmonary pressure } \\
\text { measurements }\end{array}$ \\
\hline $\begin{array}{l}\text { Differential } \\
\text { diagnosis }\end{array}$ & $\begin{array}{l}\text { - Heart failure (prior anthracycline } \\
\text { toxicity or conditioning with CY) } \\
\text { - Endothelial syndromes: SOS, CLS, ES } \\
\text { (see Chaps. } 42 \text { and } 49 \text { ) } \\
\text { - Respiratory tract infections } \\
\text { - Post transfusion reactions }\end{array}$ \\
\hline Treatı & Hydro-saline restriction, diuretics \\
\hline
\end{tabular}

\subsection{Idiopathic Pneumonia Syndrome}

\subsubsection{Definition}

Widespread alveolar injury in absence of active lower respiratory tract infection, cardiac or renal dysfunction, and iatrogenic fluid overload (Clark et al. 1993; Panoskaltsis-Mortari et al. 2011) 


\subsubsection{Clinical Manifestations}

Characterized by development around day +20 after HSCT of fever and nonproductive cough, dyspnea, tachypnea, hypoxemia, rales, and diffuse alveolar or interstitial infiltrates on x-rays or CT scans.

\subsubsection{Diagnosis}

All of the following must be present for accepting the IPS diagnosis:

\section{Evidence of widespread alveolar injury}

(a) Multilobar infiltrates on chest radiographs or CT

(b) Symptoms and signs of pneumonia (cough, dyspnea, tachypnea, crackles/rales)

(c) Evidence of abnormal pulmonary physiology Increased alveolar to arterial oxygen difference; need for supplemental $\mathrm{O}_{2}$ therapy New or increased restrictive PFTs abnormality

2. Absence of active lower respiratory tract infection based upon

(a) BAL negative for significant bacterial pathogens including acid-fast bacilli, Nocardia, and Legionella species

(b) BAL negative for pathogenic nonbacterial microorganisms (Note of the authors: Most of the following diagnostic methods despite included in the initial diagnostic methodology have nowadays largely been replaced by PCR techniques)

Routine culture for viruses and fungi

Shell vial culture for CMV and respiratory RSV

Cytology for CMV inclusions, fungi, and Pneumocystis jirovecii

Direct fluorescence staining with antibodies against CMV, RSV, HSV, VZV, influenza virus, parainfluenza virus, adenovirus, and other organisms

(c) Other organisms/tests to also consider:

PCR for human metapneumovirus, rhinovirus, coronavirus, and HHV6

PCR for Chlamydia, Mycoplasma, and Aspergillus spp.

Serum and BAL fluid GM for Aspergillus species

(d) Transbronchial biopsy if condition of the patient permits

3. Absence of

Cardiac dysfunction, acute renal failure, or iatrogenic fluid overload as etiology for pulmonary dysfunction

\subsubsection{Pathogenesis, Incidence, Presentation, and Risk Factors}

\begin{tabular}{|c|c|}
\hline Pathogenesis & $\begin{array}{l}\text { The pathophysiology of IPS is complex. Data generated using experimental models support that } \\
\text { IPS is a process in which the lung is susceptible to two distinct but interrelated pathways of } \\
\text { immune-mediated injury: a T-cell axis and an inflammatory cytokine axis. These distinct but } \\
\text { related pathways of inflammation culminate in the recruitment of immune cells to the lung leading } \\
\text { to tissue damage and dysfunction (Cooke and Yanik 2016) }\end{array}$ \\
\hline Incidence & $\begin{array}{l}\text { - The strict methodology required to establish IPS diagnosis and the increased use of RIC have } \\
\text { reduced its incidence of } 20 \% \text { to } 25 \% \text { observed } 20 \text { years ago (at that time IPS was called idiopathic } \\
\text { pneumonia) } \\
\text { - This reduction runs in parallel of the improvement in the diagnostic methodologies to detect } \\
\text { infectious pathogens. However, the frequent absence of response to the specific treatment against } \\
\text { a detected pathogen suggests that the true incidence of IPS may be underestimated } \\
\text { - Nowadays: }<10 \% \text { of allo-HSCT ( } 8 \% \text { after MAC; } 2 \% \text { after RIC) }\end{array}$ \\
\hline Timing & $\begin{array}{l}\text { - Within first } 120 \text { days after BMT, usually observed between days }+18 \text { and }+21 \\
\text { ( } 20 \text { years ago: around days }+40 \text { to }+50 \text { ) } \\
\text { - Late IPS can be observed but they are exceptional (Thompson et al. } 2017 \text { ) }\end{array}$ \\
\hline \multirow{3}{*}{$\begin{array}{l}\text { Risk factors } \\
\text { (from Cooke } \\
\text { and Yanik } \\
\text { 2016) }\end{array}$} & Older age / Karnofsky index $<90$ / higher interval diagnosis-HSCT \\
\hline & MAC or TBI ( $\geq 12$ Gy) / HLA disparity / GVHD prophylaxis with MTX \\
\hline & Acute GVHD/previous viral infection / other malignancies than leukemia \\
\hline
\end{tabular}




\subsubsection{Treatment and Prognosis}

\begin{tabular}{|c|c|}
\hline $\begin{array}{l}\text { Supportive } \\
\text { measures }\end{array}$ & $\begin{array}{l}\text { - Supplemental } \mathrm{O}_{2} \text { therapy } \\
\left.\text { - Mechanical ventilation (invasive or not [high-flow nasal } \mathrm{O}_{2}, \mathrm{CPAP}\right] \text { ) } \\
\text { - Empiric broad-spectrum antimicrobials } \\
\text { - Strict control of fluids balance/hemofiltration }\end{array}$ \\
\hline $\begin{array}{l}\text { Specific } \\
\text { treatment }\end{array}$ & $\begin{array}{l}\text { As mentioned, lung injury in IPS can occur through two pathways, the TNF-alfa/LPS dependent and } \\
\text { IL6/IL17 dependent (Cooke and Yanik 2016); consequently, treatment options are focused in these } \\
\text { directions } \\
\text { - Methyl-PDN } \leq 2 \mathrm{mg} / \mathrm{kg} / \mathrm{d} \text {; if not clear response, consider as soon as possible: } \\
\text { - Anti-TNF } \text { : Etanercept } 0.4 \mathrm{mg} / \mathrm{kg} \text { twice weekly (maximum of } 8 \text { doses) + systemic steroids ( } 2 \mathrm{mg} / \\
\mathrm{kg} / \mathrm{d} \text { ). The randomized study of etanercept + steroids vs. steroids + placebo was terminated } \\
\text { prematurely due to slow accrual. In the limited number of patients examined, there were no } \\
\text { differences in response rates }(\approx 60 \% \text { ) at day }+28 \text {. These results do not necessarily imply that this } \\
\text { agent is not effective (lack of evidence does not imply lack of effectiveness) (Yanik et al. 2014). In a } \\
\text { phase II trial in children, the CR rate was } 71 \% \text { and } 1 \text { y survival was } 63 \% \text { (Yanik et al. 2015). This } \\
\text { combination has also been shown to be effective in exceptional cases of late IPS with a } 42 \% \text { of CR } \\
\text { and a } 2 \text { y survival of } 62 \% \text { among responders (Thompson et al. 2017) } \\
\text { - Other investigational agents such as } \\
\text { - MoAb anti-IL6: Tocilizumab (experimental IPS; Varelias et al. 2015) } \\
\text { - MoAb anti-IL17: Brodalumab (experimental IPS; Varelias et al. 2015) }\end{array}$ \\
\hline Evolution & $\begin{array}{l}\text { Despite the diagnosis and therapeutic advances, the mortality from IPS remains high at } 59-80 \% \text { at } \\
\approx 2 \text { weeks of evolution ( } 95 \% \text { if mechanical ventilation is required) }\end{array}$ \\
\hline
\end{tabular}

\subsection{Diffuse Alveolar Hemorrhage (DAH)}

Diffuse alveolar hemorrhage (DAH) is a relevant cause of acute respiratory failure that occurs in $2-14 \%$ of recipients, with similar incidence in both auto- and allo-HSCT recipients (Afessa et al. 2002a).
DAH is probably a consequence of damage to the alveolar capillary basement membrane (see Chap. 42). It is difficult to differentiate a true DAH from the alveolar hemorrhage associated with an infection (Majhail et al. 2006).

\subsubsection{Clinical Aspects of DAH}

\begin{tabular}{l|l}
$\begin{array}{l}\text { Clinical } \\
\text { manifestations }\end{array}$ & $\begin{array}{l}\text { Usually observed within the first month after HSCT (a median of } 23 \text { days), often during the } \\
\text { pre-engraftment phase; however, later onset is encountered in up to } 42 \% \text { of cases } \\
\text { The clinical manifestations are those of all IPS. Hemoptysis is exceptional }\end{array}$ \\
Diagnosis & $\begin{array}{l}\text { Based on BAL: Same criteria as IPS plus a differential characteristic; the progressive bloodier return of } \\
\text { BAL fluid aliquots, in at least three segmental bronchi, indicating the presence of blood in the alveoli (or } \\
\text { 20\% hemosiderin-laden macrophage, although their absence does not exclude the diagnosis as it can } \\
\text { take } 72 \text { h to appear). Note: DAH can have infectious or noninfectious etiologies (Majhail et al. 2006) }\end{array}$ \\
\hline Risk factors & $\begin{array}{l}\text { - Higher incidence after TBI and high-dose CY } \\
\text { - Similar incidence among MAC and RIC }\end{array}$ \\
- There is no correlation with the platelet counts \\
- Classic IPS: Very difficult, only by means of BAL. IPS usually appears after the engraftment, \\
predominates in allo-HSCT, does not respond to steroids, and progresses to fibrosis in $85 \%$ of \\
diagnosis with \\
cases (only 15\% on DAH). Note: Noninfectious DAH falls under the "diagnostic umbrella" of IPS \\
(Panoskaltsis-Mortari et al. 2011) \\
- PERDS: Almost impossible except for LBA progressively bloodier \\
- Pulmonary hemorrhage: By FOB, no blood is seen in DAH \\
- DAH associated with infection: Impossible without detection of the pathogen (Majhail et al. \\
2006)
\end{tabular}




\subsubsection{Treatment and Prognosis of DAH}

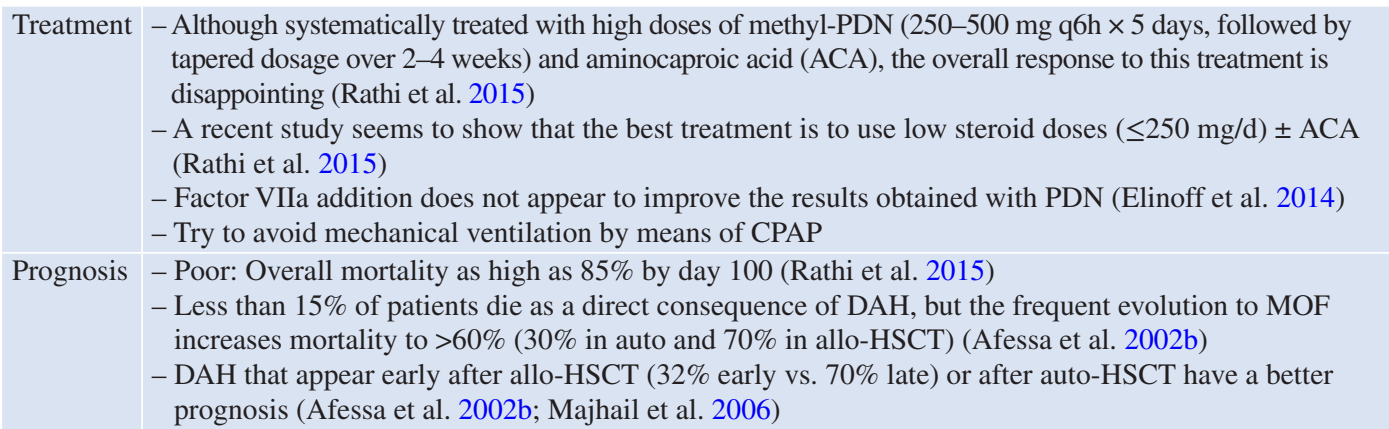

\subsection{Late-Onset Noninfectious Pulmonary Complications (LONIPC)}

In addition to late-onset IPS mentioned before and some other exceptional complications (thromboembolisms, pneumomediastinum), there are two forms of chronic pulmonary dysfunction commonly observed in patients surviving more than 100 days after allo-HSCT. One is an obstructive lung disease (bronchiolitis obliterans syndrome, $B O S$ ) and the other a restrictive lung disease (cryptogenetic organizing pneumonia, $C O P)$.

A recent prospective study showed that among 198 patients included after day +100 , the cumulative incidence of LONIPC is $20 \%$, and that of BOS is $11 \%$ at 3 years among alloHSCT recipients (Bergeron et al. 2018). Another study shows the impact of these complications on 5-year survival (28\% with vs. $87 \%$ w/o LONIPC) (Nishio et al. 2009).

\subsubsection{Bronchiolitis Obliterans Syndrome (BOS)}

Pathogenesis, timing, incidence, clinical manifestations, diagnosis, and radiology of BOS are shown in Table 52.2.

Treatment and prognosis of BOS are included in Table 52.3.

\subsubsection{Cryptogenetic Organizing Pneumonia (COP)}

Formerly called BOOP (bronchiolitis obliterans with organizational pneumonia). $\mathrm{COP}$ is a LONIPC of that is associated with restrictive pulmonary dysfunction. Reportedly, the incidence of COP among HSCT recipients is increasing due to the use of transbronchial biopsies as diagnostic tool. The greatest diagnostic challenge is the differentiation of COP from BOS (see Table 52.4) (Yoshihara et al. 2007; Cooke et al. 2017).

Table 52.2 Main clinical characteristics of BOS

\begin{tabular}{|c|c|}
\hline Pathogenesis & $\begin{array}{l}\text { The same as cGVHD but specifically involving the lung (Cooke et al. 2017). Its course may be } \\
\text { aggravated by respiratory infections, viral infections, and gastroesophageal reflux }\end{array}$ \\
\hline $\begin{array}{l}\text { Timing and } \\
\text { incidence }\end{array}$ & $\begin{array}{l}\text { - Average starting period: } 12 \text { (3-24) months } \\
\text { - Incidence: } 3 \% \text { at } 2 \text { years in the longest series (Arora et al. 2016); } 11 \% \text { in a prospective study } \\
\text { (Bergeron et al. 2018) }\end{array}$ \\
\hline $\begin{array}{l}\text { Clinical } \\
\text { manifestations }\end{array}$ & $\begin{array}{l}\text { - Variable clinical course, usually insidious onset with progressive deterioration. Sometimes can } \\
\text { present as an acute, fulminating course } \\
\text { - Progressive breathlessness, nonproductive cough, and wheezing, although some asymptomatic } \\
\text { cases are only detected by PFTs. } \\
\text { - It is necessary to carry out PFT every } 3 \mathrm{~m} \text { in the first year after HSCT for an early detection }{ }^{\mathrm{a}} \\
\text { - In }>75 \% \text { of the BOS, there are chronic GVHD in other locations }\end{array}$ \\
\hline
\end{tabular}


Table 52.2 (continued)

Diagnosis - Suspicion: The so-called BOS stage Op. More than $85 \%$ of cases can be diagnosed early by observing a 10-19\% drop in the FEV1 or a reduction in FEF25-75 > 25\% (Abedin et al. 2015)

- Clinical (NIH consensus) (Chien et al. 2010; Uhlving et al. 2012)

- Clinical manifestation (may be asymptomatic and only detected on PFT) +

- Absence of active infection (demonstrated by BAL) +

- Chronic GVHD in other locations ${ }^{\mathrm{b}}+$

- Obstructive alteration with air entrapment (FEV1 $<75 \%$ NV or $>10 \%$ decrease; ratio

FEV1/FVC ratio $<0.7$; residual volume $>120 \%$ ) with nonsignificant bronchodilator test and a decreased DLCO +

- Compatible radiology (see below)

- Definitive: Histologic confirmation by thoracotomy, VATS, or transbronchial biopsy ${ }^{c}$

Radiology

- Chest x-ray: Normal or with signs of hyperinflation

- CT scan: Radiological pattern of constrictive bronchiolitis with aerial entrapment, attenuation in mosaic, bronchiectasis and bronchial wall thickening, characteristic air trapping at exhalation

$D L C O$ transfer capacity of $\mathrm{CO}, F E V 1$ maximum expiratory volume in the first second, $F V C$ forced vital capacity, VATS video-assisted thoracoscopic surgery

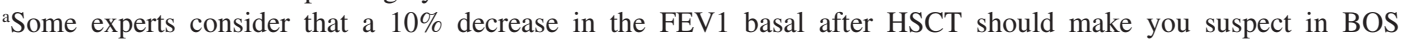
diagnosis

'If the lung is the only organ with cGVHD, a biopsy is needed to confirm the diagnosis (NIH criteria)

'Rarely transbronchial biopsy is used (low sensitivity and low predictive value) to establish a diagnosis that is eminently clinical. If histology is available, the term bronchiolitis obliterans can be used; if not available, the process is referred to as BOS

Table 52.3 Treatment and prognosis of BOS

Treatment Supportive measures:

Anti-infectious prophylaxis

If hypogammaglobulinemia: IVIg

Treatment of gastroesophageal reflux

Respiratory physiotherapy

Specific treatment

- Prednisone: $1-1.5 \mathrm{mg} / \mathrm{kg} / \mathrm{day}$, transient and unsatisfactory response in most cases. The addition of CSA, azathioprine, ATG, or photopheresis has few advantages

- Budesonide/inhaled formoterol has been shown to be transiently effective in $60 \%$ of the patients (Bergeron et al. 2015)

- Etanercept/infliximab: Effective in some cases (Yanik et al. 2012)

- FAM combination therapy: Effective in disease stabilization ${ }^{\mathrm{a}}$ :

- Fluticasone inhaled $440 \mathrm{mcg} \mathrm{c} / 12 \mathrm{~h}$ (adult), $220 \mathrm{mcg}$ in children +

- Azithromycin $250 \mathrm{mg} / \mathrm{d}$ (adults), $5 \mathrm{mg} / \mathrm{kg} / \mathrm{d}$ (children) ${ }^{\mathrm{b}}+$

- Montelukast $10 \mathrm{mg}$ orally at night (adults), $5 \mathrm{mg}$ (children)

Two weeks before FAM increase (or start) PDN to $1 \mathrm{mg} / \mathrm{kg} / \mathrm{d}$, then decrease $0.25 \mathrm{mg} / \mathrm{kg} / \mathrm{d} \times$ week (Williams et al. 2015)

- In BOS controlled but with a severe residual respiratory insufficiency, lung transplantation may be considered after a few years (Cheng et al. 2014)

Prognosis - TRM is very high; $32 \%(18-57 \%)$ at 2 years of HSCT almost always get associated with progressive respiratory failure and opportunistic infections

- SRV around $65 \%(4 \%-80 \%)$ at 2 years

${ }^{a}$ Fluticasone theoretically decreases the inflammatory pulmonary component; azithromycin reduces IL- 8 levels and neutrophilia; and montelukast is an antagonist of the leukotriene receptors (bronchodilator)

${ }^{b}$ However, the ALLOZITHRO randomized trial has shown that early administration of azithromycin resulted in worse airflow decline-free survival than did placebo; the value of these findings is limited by early termination of the trial (Bergeron et al. 2017) 
Table 52.4 Differential diagnosis between BOS and COP

\begin{tabular}{|c|c|}
\hline First symptoms & $\begin{array}{l}\text { BOS: >day }+100 \text { HSCT } \\
\text { COP: Mostly in the first } 100 \text { days }^{\text {a }}\end{array}$ \\
\hline Incidence & $\begin{array}{l}\text { BOS: } 3-11 \% \text { allo-HSCT ( } 35 \% \text { if cGVHD) } \\
\text { COP: Up to } 10 \% \text { in URD HSCT }\end{array}$ \\
\hline Clinical context & $\begin{array}{l}\text { BOS: Allo-HSCT with cGVHD } \\
\text { COP: Auto- or allo-HSCT. Almost always previous respiratory infection }\end{array}$ \\
\hline Symptoms, signs & $\begin{array}{l}\text { BOS: Asymptomatic, or progressive breathlessness, dry cough, wheezing. No fever, } \\
\text { normal blood test } \\
\text { COP: Fever, dry cough. Leukocytosis, increased CRP }\end{array}$ \\
\hline Etiology & $\begin{array}{l}\text { BOS: cGVHD } \\
\text { COP: Idiopathic? Triggered by infection }{ }^{\mathrm{b}} \text { or } \text { drugs }^{\mathrm{c}} \text { ? }\end{array}$ \\
\hline Pulmonary auscultation & $\begin{array}{l}\text { BOS: Wheezing, hypoventilation } \\
\text { COP: Crackles/rales }\end{array}$ \\
\hline RFT & $\begin{array}{l}\text { BOS: Obstructive pattern: FEV1/FVC }<70 \% \text {, FEV } 1<75 \% \text {, DLCO reduced } \\
\text { COP: Restrictive pattern: FEV1/FVC }>80 \%, \text { TLC }<80 \% \text {, DLCO reduced }\end{array}$ \\
\hline Chest radiology & $\begin{array}{l}\text { BOS: Normal or airtrapping } \\
\text { COP: Alveolar or interstitial pattern }\end{array}$ \\
\hline Thoracic CT scan & $\begin{array}{l}\text { BOS: Thickening of bronchial walls, bronchiectasis, air trapping on expiratory views } \\
\text { COP: Uni- or bilateral patched bindings, glass images dull, or nodular infiltrators }\end{array}$ \\
\hline BAL & $\begin{array}{l}\text { BOS: Neutrophilia } \\
\text { COP: Lymphocytosis, decreased CD4/CD8 ratio }\end{array}$ \\
\hline Diagnosis & $\begin{array}{l}\text { BOS: Clinical manifestations }+ \text { PFTs }+ \text { radiology } \\
\text { COP: Requires lung biopsy }\end{array}$ \\
\hline Response to steroids & $\begin{array}{l}\text { BOS: Limited } \\
\text { COP: Response in }>80 \%\end{array}$ \\
\hline Prognosis & $\begin{array}{l}\text { BOS: SRV }<20 \% \text { at } 5 \text { years if no response to steroids } \\
\text { COP: Potentially reversible }\end{array}$ \\
\hline
\end{tabular}

$C R P$ C-reactive protein

af patients are adequately controlled, it is common to detect restrictive alterations before the day +100 although clinical manifestations may appear later

${ }^{\mathrm{b}}$ Mycoplasma, Coxiella, Nocardia, and various viruses

${ }^{\mathrm{c}}$ Amiodarone, bleomycin, busulfan, and cephalosporins

\section{Key Points}

- Lung injury occurs frequently following HSCT and significantly contributes to morbidity and mortality in the immediate post transplant period and in the months and years that follow. It can be observed in $25-55 \%$ of recipients.

- Noninfectious lung injury following HSCT may be mediated by either immune or nonimmune mechanisms and could represent up to the $50 \%$ of noninfectious mortality after allo-HSCT.
- Most relevant noninfectious early pulmonary complications are pulmonary edema by fluid overflow, idiopathic pneumonia syndrome, and diffuse alveolar hemorrhage, a vascular endothelial syndrome.

- The most relevant late-onset noninfectious pulmonary complications are bronchiolitis obliterans and cryptogenetic organizing pneumonia.

- All of them have specific diagnostic criteria, management, treatment, and prognosis. 


\section{References}

Abedin S, Yanik GA, Braun T, et al. Predictive value of bronchiolitis obliterans syndrome stage $0 p$ in chronic graft-versus-host disease of the lung. Biol Blood Marrow Transplant. 2015;21:1127-31.

Afessa B, Tefferi A, Litzow MR, Peters SG. Outcome of diffuse alveolar hemorrhage in hematopoietic stem cell transplant recipients. Am J Respir Crit Care Med. 2002a; 166:1364-8.

Afessa B, Tefferi A, Litzow MR, et al. Diffuse alveolar hemorrhage in hematopoietic stem cell transplant recipients. Am J Respir Crit Care Med. 2002b;166:641-5.

Arora M, Cutler CS, Jagasia MH, et al. Late Acute and Chronic Graft-versus-Host Disease after Allogeneic Hematopoietic Cell Transplantation. Biol Blood Marrow Transplant. 2016;22:449-55.

Bergeron A, Chevret S, Chagnon K, et al. Budesonide/formoterol for bronchiolitis obliterans after hematopoietic stem cell transplantation. Am J Respir Crit Care Med. 2015;191:1242-9.

Bergeron A, Chevret S, Granata A, et al. Effect of azithromycin on airflow decline-free survival after allogeneic hematopoietic stem cell transplant: the ALLOZITHRO randomized clinical trial. JAMA. 2017;318:557-66.

Bergeron A, Chevret S, Peffault de Latour R, et al. Noninfectious lung complications after allogeneic haematopoietic stem cell transplantation. Eur Respir J. 2018;51(5):1702617. https://doi. org/10.1183/13993003.02617-2017.

Cheng GS, Edelman JD, Madtes DK, Martin PJ, Flowers ME. Outcomes of lung transplantation after allogeneic hematopoietic stem cell transplantation. Biol Blood Marrow Transplant. 2014;20:1169-75.

Chien JW, Duncan S, Williams KM, Pavletic SZ. Bronchiolitis obliterans syndrome after allogeneic hematopoietic stem cell transplantation-an increasingly recognized manifestation of chronic graft versus-host disease. Biol Blood Marrow Transplant. 2010;16(1 Suppl):S106-14.

Clark JG, Hansen JA, Hertz MI, et al. NHLBI workshop summary. Idiopathic pneumonia syndrome after bone marrow transplantation. Am Rev Respir Dis. 1993;147(6 Pt. 1):1601-6.

Cooke KR, Yanik GA. Lung injury following hematopoietic cell transplantation. In: Forman SJ, Negrin RS, Antin JH, Appelbaum FR, editors. Thomas' hematopoietic cell transplantation. 5th ed. Hoboken: Wiley; 2016. p. 1157-70.

Cooke KR, Luznik L, Sarantopoulos S, et al. The biology of chronic graft-versus-host disease: a task force report from the National Institutes of Health Consensus Development Project on Criteria for Clinical Trials in Chronic Graft-Versus-Host Disease. Biol Blood Marrow Transplant. 2017;23:211-34.

Elinoff JM, Bagci U, Moriyama B, et al. Recombinant human factor VIIa for alveolar hemorrhage follow- ing allogeneic stem cell transplantation. Biol Blood Marrow Transplant. 2014;20:969-78.

Lucena CM, Torres A, Rovira M, et al. Pulmonary complications in hematopoietic SCT: a prospective study. Bone Marrow Transplant. 2014;49:1293-9.

Majhail NS, Parks K, Defor TE, Weisdorf DJ. Diffuse alveolar hemorrhage and infection-associated alveolar hemorrhage following hematopoietic stem cell transplantation: related and high-risk clinical syndromes. Biol Blood Marrow Transplant. 2006;12:1038-46.

Nishio N, Yagasaki H, Takahashi Y, et al. Late-onset non-infectious pulmonary complications following allogeneic hematopoietic stem cell transplantation in children. Bone Marrow Transplant. 2009;44: 303-8.

Panoskaltsis-Mortari A, Griese M, Madtes DK, et al. An official American Thoracic Society research statement: noninfectious lung injury after hematopoietic stem cell transplantation: idiopathic pneumonia syndrome. Am J Respir Crit Care Med. 2011;183:1262-79.

Rathi NK, Tanner AR, Dinh A, et al. Low-, mediumand high-dose steroids with or without aminocaproic acid in adult hematopoietic SCT patients with diffuse alveolar hemorrhage. Bone Marrow Transplant. 2015;50:420-6.

Rondón G, Saliba RM, Chen J, et al. Impact of fluid overload as new toxicity category on hematopoietic stem cell transplantation outcomes. Biol Blood Marrow Transplant. 2017;23:2166-71.

Seo S, Renaud C, Kuypers JM, et al. Idiopathic pneumonia syndrome after hematopoietic cell transplantation: evidence of occult infectious etiologies. Blood. 2015;125:3789-97.

Shannon VR, Andersson BS, Lei X, et al. Utility of early versus late fiberoptic bronchoscopy in the evaluation of new pulmonary infiltrates following hematopoietic stem cell transplantation. Bone Marrow Transplant. 2010;45:647-55.

Thompson J, Yin Z, D'Souza A, et al. Etanercept and corticosteroid therapy for the treatment of late-onset idiopathic pneumonia syndrome. Biol Blood Marrow Transplant. 2017;23:1955-60.

Uhlving HH, Buchvald F, Heilmann CJ, et al. Bronchiolitis obliterans after allo-SCT: clinical criteria and treatment options. Bone Marrow Transplant. 2012;47:1020-9.

Varelias A, Gartlan KH, Kreijveld E, et al. Lung parenchyma-derived IL-6 promotes IL-17Adependent acute lung injury after allogeneic stem cell transplantation. Blood. 2015;125:2435-44.

Williams KM, Cheng GS, Pusic I, et al. Fluticasone, Azithromycin, and Montelukast Treatment for NewOnset Bronchiolitis Obliterans Syndrome after Hematopoietic Cell Transplantation. Biol Blood Marrow Transplant. 2016;22:710-6.

Yanik GA, Grupp SA, Pulsipher MA, et al. TNF-receptor inhibitor therapy for the treatment of children with idiopathic pneumonia syndrome. A joint Pediatric Consortium and Children's Oncology Group Study (ASCT0521). Biol Blood Marrow Transplant. 2015;21:67-73. 
Yanik GA, Horowitz MM, Weisdorf DJ, et al. Randomized, double-blind, placebo-controlled trial of soluble tumor necrosis factor receptor: enbrel (etanercept) for the treatment of idiopathic pneumonia syndrome after allogeneic stem cell transplantation: blood and marrow. Biol Blood Marrow Transplant. 2014;20:858-64.

Yanik GA, Mineishi S, Levine JE, et al. Soluble tumor necrosis factor receptor: enbrel (etanercept) for sub-acute pulmonary dysfunction following alloge- neic stem cell transplantation. Biol Blood Marrow Transplant. 2012;18:1044-54.

Yoshihara S, Yanik G, Cookee KR, Mineishi S. Bronchiolitis obliterans syndrome (BOS), bronchiolitis obliterans organizing pneumonia (BOOP), and other late-onset noninfectious pulmonary complications following allogeneic hematopoietic stem cell transplantation. Biol Blood Marrow Transplant. 2007;13:749-79.

Open Access This chapter is licensed under the terms of the Creative Commons Attribution 4.0 International License (http://creativecommons.org/licenses/by/4.0/), which permits use, sharing, adaptation, distribution and reproduction in any medium or format, as long as you give appropriate credit to the original author(s) and the source, provide a link to the Creative Commons license and indicate if changes were made.

The images or other third party material in this chapter are included in the chapter's Creative Commons license, unless indicated otherwise in a credit line to the material. If material is not included in the chapter's Creative Commons license and your intended use is not permitted by statutory regulation or exceeds the permitted use, you will need to obtain permission directly from the copyright holder. 